\title{
Factors of Purchase Intention Toward Social Commerce Among Young Generation in Malaysia
}

\author{
Ang Zi En ${ }^{1}$, Normala S Govindarajo², Dileep Kumar $\mathrm{M}^{3}$ \\ Xiamen University Malaysia, Sepang, Malaysia ${ }^{1,2}$, Gopal Narayan Singh University, India ${ }^{3}$ \\ \{dilaims@aol.com¹,gnmala@yahoo.com²,prof.dr.dil@gmail.com ${ }^{3}$ \}
}

\begin{abstract}
Social commerce is growing rapidly as a result of popularity of internet network. Many businesses are selling their products on social networking platforms and using the influence of social networking platforms to promote their products to all corners of the world. Besides, the development of logistics and supply chain is growth rapidly around the world. Hence, there is a business opportunity in social commerce. Next, the main objective on this research is to determine the factors that will influence purchase intention through social commerce by young generation in Malaysia and to examine do the variables have significant and positive relationship towards social commerce in Malaysia. The researcher had conducted convenience sampling and collected 160 respondents in Malaysia. Self-administered questionnaire comprises of two major sections was distributed to the respondents in 7- and 5-point Likert scale. Besides, the researcher used quantitative research method and deductive research approach to conduct the whole research. For result analysis, the researcher used different techniques to analyse the findings such as descriptive analysis, reliability analysis, normality analysis, regression analysis and validity analysis. After that, the researcher found that factors such as trust, perceived usefulness, and perceived ease of use, electronic word of mouth and subjective norm will influence youth consumers' purchase intention significantly toward social commerce in Malaysia. Lastly, this research could help Malaysia government to predict the development on this sector, help online retailers to prevent the issues and maintain the online environment in a good position and match the preference of consumers, and help social commerce industry to have a better understanding on the consumers' purchase intention.
\end{abstract}

Keywords: Social Commerce; Young Generation; Malaysia; Purchase Intention; TAM2

\section{Background Information}

Social commerce is growing rapidly as a result of popularity of internet network. Many businesses are selling their products on social networking platforms and using the influence of social networking platforms to promote their products to all corners of the world. The advantages of social commerce make the products transportation become rapidly, and help the industry of logistics become the major industry in the world. Not only that, social commerce 
also generates a new business style, let everyone can start-up their business easily and convenience. Besides that, social commerce makes the online shopping become a common shopping style in Malaysia, especially for fresh graduates. This research mainly investigates the current situation of social commerce in Malaysia, as well as the factors of influences of college students/fresh graduates purchase intention on the Social Networking Service (SNS).

\subsection{Global Perspective}

In this high-technology generation, e-commerce become more familiar, many products are traded online. As a part of e-commerce, social commerce has been booming in recent years. Social commerce is using the online social network, to do the action of trading, selling and buying products on the SMP (Market Business News, 2020). The business will use the functions of SMP such as like, share, ratings, social advertising, and online communities to promote their products. According to the digital report 2020, the active users in SMP are 3.80 billion, it is increase 321 million active users compare with January 2019. Facebook is the top platform ranking around the world which has 2,449 million active users around the world (Data Reportal, 2020). For the e-commerce, the total value of global consumer is reached 3.43 trillion in 2020, which is be a huge amount created in the global trading. This means that it has the large potential market for e-commerce even the social commerce to develop it. As a subset of e-commerce, the social commerce market also become a mainstream of the trading mode in this network technology era. According to the statistic in United State, it shows that the average order value of online shopping on SMP is around \$79.01in second quarter of 2019 (Statista, 2019), and around 1/3 of United State consumers have an experience purchased products in SMP in 2019 (E Marketer, 2019). On the basis of these statistic, the global market of social commerce can be predicted to increase rapidly and has enormous development potential in 2020, also will accept by more and more consumers in the future.

\subsection{Asia Perspective}

Asia become a main area for the goods trading nowadays and also become the most value of goods trading in SMP among the world. It is a benefit for Malaysia since we located in the major transportation hubs, our SMP development also keep pace with the world. From the global digital report, it has around 2.14 billion active SMP users in Asia Pacific in January 2020, and it became a pros for us to expand and develop the social commerce (Data Reportal, 2020). With the development of science and technology, the successful of e-payment has further expanded and help the growing of social commerce, and there is a mutually beneficial relationship between these two industries (Trybocka, 2019). On the other hand, social commerce growing up explosively in the recent years, and the two mainstreams of SMP are Facebook and twitter. In the Econsultancy Report 2019, it has mention that around $84 \%$ of the respondents in South East Asia will continuously purchase through the SMP, means that the social commerce market in South East Asia has a huge potential to develop (Econsultancy, 2019). By using the SMP to purchase, consumers also will comment or share their experience on the SMP, it will influence the others before buying the products (Econsultancy, 2019). Thus, by using the traffic of SMP to develop your commerce, the usage of the SMP such as post, like, comment and share also will affect the value of your business or commerce, both of them are the mutual relationship. $59 \%$ of the respondents are mention that the information in SMP will affect their purchase intention (Econsultancy, 2019). 


\subsection{Malaysia Perspective}

Base on the figure above, in Malaysia, it has around 26 million people active on SMP, the penetration is $81 \%$ over the total population in Malaysia, means that the potential of social commerce is very large with the large number of active users nowadays. This report also shows that Malaysian spend almost 3 hours per day on SMP. Not only that, there are $57 \%$ of Malaysian Internet users are known to use SMP for work purposes. We know that the social commerce is growth rapidly in Malaysia at this stage, even tend to be universal of the mode of doing business. For the e-commerce, there are 19.8 million people purchasing consumer goods online in 2018, which increase $2.1 \%$ compare with the previous year. As Malaysia is the major market for social commerce adopter in the world, the top 3 SMP is YouTube (93\%), WhatsApp (91\%) and Facebook (89\%) in January 2020. The development of internet and e payment are the key issues for the development of social commerce. The consumers prefer mobile-first, digital technology and instant communication. According to those issues, Malaysia's social commerce thus to grow up rapidly year by year.

\subsection{Problem Statement}

The most obvious way that the SMP affect commerce is the feedback. Real-time feedback is the message that consumer comment about the products instantly in the SMP. There are many ways for consumer do the real time feedback and pass to the sellers, such as post, like, share, comment, rating and so on. The message will directly an instantly go back to the sellers or company. Not only that, the feedback also will share with the consumers' friends and followers at the same time. If it is a phrase or positive feedback, it is become a free advertisement for your business, help you to do the publicity and will be the chance for you expand your business. Each coin has both sides, if the feedback of consumers is negative, it will affect and decrease your business value and image. The control of the negative advertisement become hard and difficult for company to solve it. Besides that, company need to pay extra funds to control the bad situation and track the defamatory of the company. On the other hand, the trust between sellers and consumers also be a main issue in social commerce.

Consumers only can analyse the condition of products with the photos and descriptions. Mostly they will compare the comment of the previous consumers to decide the purchase intention. Nonetheless the problem is, consumers cannot make sure the information in the SMP is correct and match the entity products. Sometimes will occur the situation of photos and products is different. This situation will make the trust between sellers and consumers breakdown and company will have a negative feedback. In order to explore the relation between purchase intention and social commerce among young generation a quantitative study was conducted with a sample size of 160 . Due to Covid scenario, the study limited the data collection in one university. The study followed SPSS to analyse the data. The study provide practical and theoretical implications related to the scenario researched into.

\subsection{Research Question}

Does determinants of purchase intention influence toward social commerce in Malaysia?

\subsection{Research Objective}


1. To analyse the factors that will influence purchase intention in social commerce among Gen $\mathrm{Z}$ in Malaysia.

2. To examine the significant relationship of variables towards social commerce in Malaysia.

\section{Literature Review}

\subsection{Trust towards BI}

According to the research of et al. (2014), the study investigates and predicts the determinant of Trust in the social commerce adoption, and found the result of Trust is positively affect the purchase intention in social commerce. In this study, 350 questionnaires were distributed to mobile users of Generation Y in Selangor, Johor and Perak (Krishna et al., 2014). The coefficient on this study is 0.07 , which shows that it is a positive relationship between Trust and BI. In the study of Masoodul, Zeeshan and Bakhtawar, by distributed 200 questionnaires for online shopping user, the result shows that the Trust disposition positively shape the trust in marketplace, and significantly affect the BI towards social commerce, and the standardization coefficient is 0.16 (Masoodul, Zeeshan, \& Bakhtawar, 2018). Besides that, Cho and Smitha conduct a study about the purchase intention of millennial's in social commerce by collected 384 questionnaires to determine and understand the relationship between trust and purchase intention (See, Khalil, \& Ameen, 2019). This study comprised the online purchase consumers in Malaysia and have a result of positive relationship between trust and purchase intention. Thus, based on the studies, the following hypothesis is formed.

H1: There is a significant and positive relationship between Trust and BI on social commerce.

\subsection{PU towards BI}

In accordance to Tan et al., PU has a positive relationship to the purchase intention toward social commerce. The study is collected 180 usable sample data from online shopping users in Malaysia for analysis (Tan et al., 2017). The coefficient is 0.337 and the significant level is 0.00 . Cho and Smitha conducted a research to analyse the factors affecting Malaysian young consumers' online purchase intention in SMP websites. In this study, it distributed to a random sample to online shopping users in Malaysia. The result shows that PU was positively related to purchase intention in social commerce as the coefficient is about 0.307 (See, Khalil, \& Ameen, 2019). Besides, Seyedeh, Roliana and Aryati (2014) stated PU is the key element of understanding on consumer behaviour intention on Facebook commerce (Seyedeh, Roliana, \& Aryati, 2014). This study pointed out that a positive and significant relationship between PU and $\mathrm{BI}$ in social commerce, by collected the sample data with interview sixteen students of University Technology Malaysia (UTM).

H2: There is a significant and positive relationship between PU and BI on social commerce.

\subsection{PEOU towards BI}

M. Krishna et al. have conducted a research about the mobile commerce adoption in Malaysia (M. Krishna et al., 2014). The researcher used the Technology Acceptance Model (TAM) to examine the factors will influence the mobile commerce adoption, and the PEOU is one of the variables in this research. This research collected 350 of usable data from Selangor, 
Johor and Perak and the result showed the perceived of ease of use have the significant relationship with the dependent variable, and the coefficient is 0.1226 . Besides that, the research from Tan et al. also show the positive and significant relationship between PEOU and BI in social commerce (Tan, Goh, Stany, \& Yeow, 2017). The researchers have conducted an empirical study by using TAM model and collected 180 usable sample data for analysis to examine the factors that influence the purchase intention towards social commerce. The target respondents of this research are the users of online shopping in SMPs and the coefficient is 0.355 , significant level is 0.00 . In this research, it has concluded the PEOU will affect the purchase intention through PU (Francisco, Angel F., \& Manuel J, 2014).

H3: There is a significant and positive relationship between PEOU and BI on social commerce.

H4: There is a significant and positive relationship between PEOU and PU on social commerce.

\subsection{EWOM towards BI}

Sambashiva and Acharyulu (2017) have conducted a study about examining the effect of EWOM on the customer purchase intention through value co-creation (VCC) in social networking sites (SNSs) in India (Sambashiva \& Acharyulu, 2017). The 762 samples data collected with the target respondents of Facebook users in India, and get the result of positive relationship between EWOM and the consumer purchase intention in SNS, with the correlation coefficient of 0.56 (Sambashiva \& Acharyulu, 2017). Other researcher also found the result of the significant relationship between these two variables. This study about trust factors affecting consumer's purchase intention on SOHO seller: social commerce context (Ramona, Asmidar, \& Norshakirah, 2016). EWOM is one of the independent variables in this research. Survey was conducted with identified respondents and the result is the causal relationship between EWOM and consumer purchase intention in SNS products or SOHO sellers, nut didn't show out the coefficient.

H5: There is a significant and positive relationship between EWOM and BI on social commerce.

\subsection{Towards BI}

In the study of Seyedeh, Roliana and Aryati (2014), SN is a key factor to predict the customer intention behaviour through Facebook commerce. The relationship between SNs and intention behavioural had been pointed out with the positive result (Seyedeh, Roliana, \& Aryati, 2014). Besides, according to the study of See, Khalil and Ameen (2019), the relationship of subejective norms is positive. In this study, it distributed to a random sample to online shopping users in Malaysia. 384 questionnaires are successful been collected and the result shows that $\mathrm{SN}$ was positively related to purchase intention in social commerce as the coefficient is about 0. .211 and the significant level is 0.00 (See, Khalil, \& Ameen, 2019).

H6: There is a significant and positive relationship between SN and BI on social commerce.

\subsection{Underpinning Theory}

The fundamental of Technology Acceptance Model (TAM) is the Theory of Rational Action (TRA), which was presented by Ajzen and Fishbein (1975). TRA is used to predict an individual BI, no matter he or she should or should not present that behaviour (Fishbein \& 
Ajzen, 1975). Based on TRA, Davis proposed TAM to assume that consumer's BI and stated out the main two key variables in this theory are PEOU and PU (Davis, 1989).



Fig. 1. Technology Acceptance Model (TAM) Source: (Davis, 1989)

TAM model believed that system used is decided by the BI, and BI is decided by attitude toward using and PU, attitude towards use is determined by the PU and PEOU, PU is determined by PEOU and external variables, PEOU is determined by the external variables. In many earlier studies, researchers used TAM model to discuss and examine the effect of organizational information systems. Moreover, it provides a good analytical method for product optimization and improvement, and helps the product to be more competitive in the market (Abdullah, Ahasanul, \& Farzana, 2013). Not only used in information system research, TAM model also proved to be a suitable measurement of social commerce adoption. Furthermore, use the TAM model as a base, Venkatesh and Davis (2000) had implement the TAM2 Model as the expansion of TAM model, which has included the social influence processes (SN, voluntariness, and image) and cognitive instrumental processes (job relevance, output quality, result demonstrability, and PEOU). The figure below shows that the framework of TAM Model.

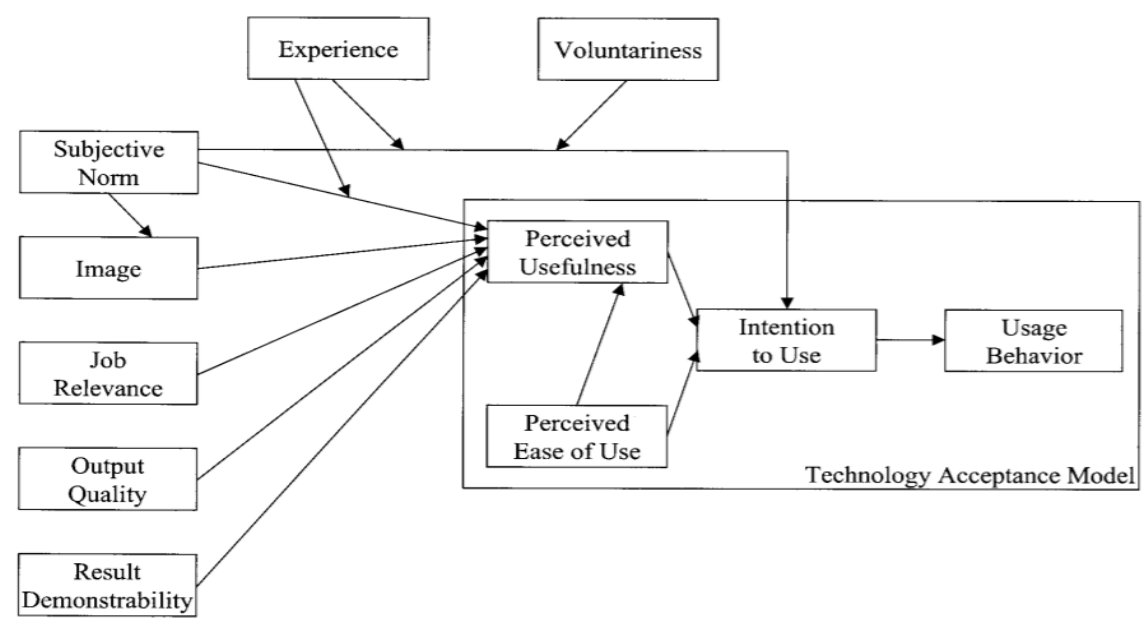


Fig. 2. Extension of Technology Acceptance Model Source: (Venkatesh \& Davis, 2000)

Thus, this study used TAM2 model used as the basis of the theoretical framework, variables in TAM model, PU and PEOU, were included in this study's research model. Besides that, trust, EWOM and SNs as additional variables was added in the research model.

\section{Research Methodology}

\subsection{Research Design}

The researcher adopted a cross sectional research design as a fundamental for the sample collection, measurement and analysis to measure the five independent variables (trust, PU, PEOU, EWOM and SN), to explore the influence of each individual variable as well as their relationship with the dependent variable (online purchase intention towards social commerce). In this research, the researcher adopted the quantitative deductive approach. The researcher adapted an instrument to examine the relationship between the dependent variable and independent variables. In this research, the independent variable is BI, whereas the independent variables, are Trust, PU, PEOU, EWOM and SN.

\subsection{Sampling}

The study followed simple random sampling and a survey was conducted from May to June 2020 and the questionnaires were distributed to the students in the targeted location, XMUM. An adequate sample size is able to represent a given population carry on a research. Since the population of students in XMUM is exceed 5000 in this research, 357 sample size is required (Krejcie \& Morgan, 1970). Due to the COVID-19 pandemic, Malaysia government had applied the MCO regulation since March 2020, the campus needs to closed and conduct with the online learning. It is affected the progress of colleting sample. At last, a total of 166 questionnaires in Likert Scales have been collected in time. Not only that, six respondents had been removed who had missing information. After collected all the sampling via online, there are a total 160 valid respondents who comprises of different background were collected successfully.

\subsection{Conceptual Framework}

The conceptual framework is a guide for researcher to establish and support research, it used to implement the steps taken throughout the research process (Akanbi, Amiri, \& Fazeldehkordi, 2015). Based on the theoretical concepts proposed in the conceptual framework, the researchers created a model to assist the entire study in philosophy, epistemology, methodology, and analysis (Grant \& Osanloo, 2014). The figure 3.2 shows the operational framework of this study, which used TAM2. 




Fig. 3. Research Framework

\subsection{Measurement of Instrumentation}

Table 1. Measurement of Instrumentation Summary

\begin{tabular}{|c|c|c|c|c|c|c|}
\hline & Variable & Author & Year & Item & $\begin{array}{c}\text { Cronbach's } \\
\text { Alpha }(\alpha) \\
\end{array}$ & Scale \\
\hline i & BI & $\begin{array}{l}\text { Viswanath Venkatesh, Michael G. } \\
\text { Morris, Gordon B. Davis, \& Fred } \\
\text { D. Davis }\end{array}$ & 2003 & 3 & $\begin{array}{c}\text { Not } \\
\text { available }\end{array}$ & $\begin{array}{c}\text { 7-point } \\
\text { Likert scales }\end{array}$ \\
\hline \multirow{5}{*}{  } & Trust & $\begin{array}{c}\text { David Gefen, Elena Karahanna, } \\
\text { \& Detmar W Straub }\end{array}$ & 2003 & 7 & $\begin{array}{c}\text { Not } \\
\text { available }\end{array}$ & $\begin{array}{c}\text { 7-point } \\
\text { Likert scales }\end{array}$ \\
\hline & PU & Fred D. Davis & 1989 & 6 & 0.970 & $\begin{array}{c}\text { 7-point } \\
\text { Likert scales }\end{array}$ \\
\hline & PEOU & Fred D. Davis & 1989 & 6 & 0.910 & $\begin{array}{c}\text { 7-point } \\
\text { Likert scales }\end{array}$ \\
\hline & $\begin{array}{l}\text { E-Word } \\
\text { of Mouth }\end{array}$ & $\begin{array}{l}\text { Man Yee Cheung, Chuan Luo, } \\
\text { Choon Ling Sia \& Huaping Chen }\end{array}$ & 2009 & 5 & 0.772 & $\begin{array}{c}\text { 5-point } \\
\text { Likert scales }\end{array}$ \\
\hline & SN & Shirley Taylor \& Peter Todd & 1995 & 6 & $\begin{array}{l}\text { Between } \\
0.690 \text { and } \\
0.950\end{array}$ & $\begin{array}{l}\text { 7-point } \\
\text { Likert scales }\end{array}$ \\
\hline
\end{tabular}

The BI instrument was adapted from Venkatesh, Morris, Davis and Davis (Venkatesh et al., 2003) which contains of 3 items with 7-point Likert scales. The trust intention instrument was adapted from David Gefen, Elena Karahanna, \& Detmar W Straub (Gefen, Karahanna, \& Straub, 2003) which contains of 7 items with 7-point Likert scales. The PU instrument was adapted from Fred D. Davis (Davis F. D., 1989) which contains of 6 items with 7-point Likert scales and a $\alpha$ of 0.970. The PEOU instrument was adapted from Fred D. Davis (Davis, 1989) which contains of 6 items with 7-point Likert scales and a $\alpha$ of 0.910. The E-Word of Mouth instrument was adapted from Man Yee Cheung, Chuan Luo, Choon Ling Sia \& Huaping Chen (Cheung, Luo, Sia, \& Chen, 2009) which contains of 5 items with 5-point Likert scales and a $\alpha$ of 0.772 . The SN instrument was adapted from Shirley Taylor \& Peter Todd (Taylor \& Todd, 1995) which contains of 6 items with 7-point Likert scales and a $\alpha$ of between 0.690 and 0.950 . 


\subsection{Validity}

Validity means effectiveness, refers to the degree to which the measured result reflects the content to be investigated (Heale \& Alison, 2015). Validity focuses on "accurate assessment" in measurement, the more the measurement result matches the content to be inspected, the higher the validity; otherwise, the lower the validity. Besides, validity can be classified into three types, which are content validity, construct validity and criterion validity (Taherdoost, 2016). The researcher used content validity and criterion validity to test the measure in this research. Content validity analyse the representativeness of the test content and the suitability of sampling, it can represent or reflect the degree of all aspects of a particular construct or variable. Conversely, content validity is also an indicator of the degree of the evaluation result of affected by other unrelated factors (Saunders, Lewis, \& Thornhill, 2009). Convergent validity shows that when measuring the same variables in different ways, the observed values should be highly correlated (Heale \& Alison, 2015). There are three criteria which are the factor loadings not more than 0.5 , average variance extracted (AVE) for the constructs should be larger than 0.5 and composite reliability (CR) above 0.7 .

\subsection{Reliability}

Reliability is dependability, which described as the degree of consistency about the results obtained when measured the same object and the same method repeatedly (Saunders, Lewis, \& Thornhill, 2009). Besides, reliability also is an indicator to estimate the degree of measurement error and to reflect the true measure. Reliability indicators are mostly expressed in correlation coefficients, which had classified into three categories: test-retest (consistency across time), inter-rater (consistency across observers), and internal consistency (consistency of the measurement itself). In this research, researcher used internal consistency to test the reliability.

\subsection{Internal Consistency}

Internal consistency reliability is one of the common methods to determine reliability (Saunders, Lewis, \& Thornhill, 2009). It refers to measure the consistency and stability of multiple measurement indicators of the same concept. In this study, researcher used $\alpha$ to test the internal consistency reliability. $\alpha$ is developed by Lee Cronbach in 1951, used as an assessment tool to measure the internal consistency reliability through defining of the positive correlation among the items (Cronbach, 1951).

\subsection{Pilot Test}

In this study, researcher run the pilot study after collected 30 respondents via online. According to Table 3.5, there were total 33 items in 7 components, which are 3 items from BI, 7 items from Trust, 6 items form PU, 6 items from PEOU, 5 items from EWOM and 6 items from SN before the pilot test. From the result of pilot test, all the items score is higher than 0.5 which means that 33 items in the questionnaire are accurate and logical. 
Table 2. Component Matrix

\begin{tabular}{|c|c|c|c|c|c|c|}
\hline & \multicolumn{6}{|c|}{ Component Matrix } \\
\hline & 1 & 2 & 3 & 4 & 5 & 6 \\
\hline BI1 & .589 & & & & & \\
\hline $\mathrm{BI} 2$ & .598 & & & & & \\
\hline $\mathrm{BI} 3$ & .644 & & & & & \\
\hline $\mathrm{T} 1$ & & .711 & & & & \\
\hline $\mathrm{T} 2$ & & .550 & & & & \\
\hline T3 & & .539 & & & & \\
\hline $\mathrm{T} 4$ & & .511 & & & & \\
\hline T5 & & .666 & & & & \\
\hline T6 & & .694 & & & & \\
\hline $\mathrm{T} 7$ & & .549 & & & & \\
\hline PU1 & & & .670 & & & \\
\hline PU2 & & & .586 & & & \\
\hline PU3 & & & .545 & & & \\
\hline PU4 & & & .737 & & & \\
\hline PU5 & & & .782 & & & \\
\hline PU6 & & & .751 & & & \\
\hline PEOU1 & & & & .829 & & \\
\hline PEOU2 & & & & .760 & & \\
\hline PEOU3 & & & & .692 & & \\
\hline PEOU4 & & & & .761 & & \\
\hline PEOU5 & & & & .765 & & \\
\hline PEOU6 & & & & .829 & & \\
\hline EWOM1 & & & & & .578 & \\
\hline EWOM2 & & & & & .560 & \\
\hline EWOM3 & & & & & .587 & \\
\hline EWOM4 & & & & & .610 & \\
\hline EWOM5 & & & & & .601 & \\
\hline SN1 & & & & & & .703 \\
\hline SN2 & & & & & & .545 \\
\hline SN3 & & & & & & .700 \\
\hline SN4 & & & & & & .596 \\
\hline SN5 & & & & & & .563 \\
\hline SN6 & & & & & & .624 \\
\hline
\end{tabular}

Extraction Method: Principal Component Analysis.

a. 7 components extracted.

The Kaiser-Meyer-Olkin Measure of Sampling Adequacy refers to a statistical test, used to compare simple correlation coefficient and partial correlation coefficient between variables and indicates the proportion of variance (IBM $\AA, 2020)$. The range of KMO is between 0 to 1 , when the value of KMO close to 1 (higher value), means that the correlation between variables is stronger, and the factor analysis will be more useful with your data. On the contrary, when the value of KMO close to 0 (lower value) or lower than 0.5 , means that the correlation between variables is weak, and the factor analysis won't be very useful with your data. On the other hand, Bartlett's test used to check unity and identity of the correlation matrix, and check whether each variable is independent. According to Table 3.6, the KMO of Sampling Adequacy during the pilot test in this research was 0.873 which is higher than 0.5 . It is adequate and the factor analysis will be more useful with this research's data. At the same time, there are a high significance in Bartlett's test of Sphericity which are 0.000. 
Table 3. KMO and Bartlett's Test

\begin{tabular}{llr}
\hline \multicolumn{3}{c}{ KMO and Bartlett's Test } \\
\hline Kaiser-Meyer-Olkin Measure of Sampling Adequacy. & $\mathbf{. 8 7 3}$ \\
\hline \multirow{3}{*}{ Bartlett's Test of Sphericity } & Approx. Chi-Square & 4660.233 \\
& Df & 528 \\
& Sig. & .000 \\
\hline
\end{tabular}

\subsection{Reliability Analysis}

Table 4. Reliability Statistics

\begin{tabular}{ccc}
\hline Variable & Number of Item & $\boldsymbol{\alpha}$ \\
\hline BI & 3 & 0.950 \\
Trust & 7 & 0.829 \\
PU & 6 & 0.875 \\
PEOU & 6 & 0.928 \\
EWOM & 5 & 0.897 \\
SN & 6 & 0.865 \\
\hline
\end{tabular}

$\alpha$ is mainly used to evaluate the consistency of continuous variables and ordered categorical variables, which is applicable to the research data of this study (CRONBACH, 1951). On the other words, Cronbach's $\alpha$ used by researchers to demonstrate the test and scale to interpret the reliability of each variable in the study project (Saunders, Lewis, \& Thornhill, 2012). The measured of $\alpha$ coefficient can be indicated from 0 (no reliability) to 1 (complete reliability). In general, the coefficient of Cronbach's $\alpha$ in exploratory research is above 0.6 and the coefficient of Cronbach's $\alpha$ in benchmark research is above 0.8 . According to Nunnally (1978), the coefficient of $\alpha$ above 0.6 is considered to be highly reliable. There are 3 items in BI, 7 items in trust, 6 items in PU, 6 items in PEOU, 5 items in EWOM and 6 items in SN. All of the Cronbach's $\alpha$ is between 0.829 and 0.950 and it is above the cut-off point of 0.60 as mentioned. As a result, the scales obtained in the research are acceptable and reliable.Moreover, the highest value of Cronbach's $\alpha$ is BI which is 0.950 . Additionally, $\alpha$ for trust is 0.829 , for PU is 0.875 , for PU is 0.928 , EWOM is 0.897 and for $\mathrm{SN}$ is 0.865 . This result shows that all the independent variables have a very good level of Cronbach's $\alpha$.

\subsection{Regression Analysis}

H1: There is a significant and positive relationship between Trust and BI on social commerce.

Table 5. Model Summary of Trust

\begin{tabular}{lcccc}
\hline \multicolumn{5}{c}{ Model Summary } \\
\hline Model & \multirow{2}{*}{ R } & R Square & Adjusted R Square & Std. Error of the Estimate \\
\hline 1 & $.447^{\text {a }}$ & .200 & .195 & .67322 \\
\hline $\begin{array}{l}\text { a. Predictors: (Constant), } \\
\text { NewT }\end{array}$
\end{tabular}

Table 4.20 shows the model summary of BI and the Trust. In the column labelled R, the value is 0.447 indicated that there is a positive and low correlation between the BI (outcome) and Trust (predictor) in the model. Besides, the $\mathrm{R}^{2}$ is 0.200 which means that Trust accounts for $20 \%$ as a cause of BI. 
Table 6. ANOVA of Trust

\begin{tabular}{ccccccc}
\hline \multicolumn{7}{c}{ ANOVA $^{\mathrm{a}}$} \\
\hline & Model & Sum of Squares & Df & Mean Square & F & Sig. \\
\hline \multirow{2}{*}{1} & Regression & 17.883 & 1 & 17.883 & 39.458 & $.000^{\mathrm{b}}$ \\
& Residual & 71.610 & 158 & .453 & & \\
& Total & 89.494 & 159 & & & \\
\hline
\end{tabular}

a. Dependent Variable: NewBI

b. Predictors: (Constant), NewT

Table 4.22 display that $\mathrm{F}=39.458$ and the are significant level is 0.05 in which the $\mathrm{p}$-value of the finding is 0.000 , less than 0.05 . Thus, this model has explained a significant relationship between Trust and BI.

Table 7. Coefficient of Trust

\begin{tabular}{|c|c|c|c|c|c|c|}
\hline \multicolumn{7}{|c|}{ Coefficient $^{\mathrm{a}}$} \\
\hline & \multirow[t]{2}{*}{ Model } & & $\begin{array}{l}\text { Indardized } \\
\text { efficients }\end{array}$ & $\begin{array}{c}\text { Standardized } \\
\text { Coefficients }\end{array}$ & \multirow[t]{2}{*}{$\mathrm{t}$} & \multirow[t]{2}{*}{ Sig. } \\
\hline & & B & Std. Error & Beta & & \\
\hline \multirow[b]{2}{*}{1} & (Constant) & .576 & .271 & & 2.128 & .035 \\
\hline & NewT & .669 & .106 & .447 & 6.282 & .000 \\
\hline
\end{tabular}

The Coefficients table (Table 4.23) provides information to explain BI in term of Trust. The $\beta$ value is 0.669 in Table 4.23 , which shows a positive relationship between the Trust and BI. Therefore, as Trust increase, BI will increase.

H2: There is a significant and positive relationship between PU and BI on social commerce.

Table 8. Model Summary of PU

\begin{tabular}{ccccc}
\hline \multicolumn{5}{c}{ Table 8. Model Summary of PU } \\
\hline \multicolumn{5}{c}{ Model Summary } \\
\hline Model & R & R Square & Adjusted R Square & Std. Error of the Estimate \\
\hline 1 & $.182^{\text {a }}$ & .033 & .027 & .74000 \\
\hline a. Predictors: (Constant), NewPU & & \\
\hline
\end{tabular}

Table 4.24 shows the model summary of BI and the PU. In the column labelled R, the value is 0.182 indicated that there is a positive and negligible correlation between the BI (outcome) and PU (predictor) in the model. Besides, the $\mathrm{R}^{2}$ is 0.033 which means that PU accounts for $3.3 \%$ as a cause of BI.

Table 9. ANOVA of PU

\begin{tabular}{llccccc}
\hline \multicolumn{7}{c}{ ANOVA $^{\text {a }}$} \\
\hline & Model & Sum of Squares & Df & Mean Square & F & Sig. \\
\hline \multirow{4}{*}{1} & Regression & 2.972 & 1 & 2.972 & 5.428 & $.021^{\mathrm{b}}$ \\
& Residual & 86.521 & 158 & .548 & & \\
\multicolumn{2}{l}{ Total } & 89.494 & 159 & & & \\
\hline a. Dependent Variable: NewBI & & & & \\
b. Predictors: (Constant), NewPU
\end{tabular}


Table 4.25 display that $\mathrm{F}=5.428$ and the significant level is 0.05 in which the $\mathrm{p}$-value of the finding is 0.021 , less than 0.05 . Thus, this model has explained a significant relationship between PU and BI.

Table 10. Coefficients of PU

\begin{tabular}{lccccc}
\hline \multicolumn{5}{c}{ Coefficients $^{\mathbf{a}}$} \\
\hline \multirow{2}{*}{ Model } & Unstandardized Coefficients & Standardized Coefficients & \\
\cline { 2 - 6 } & B & Std. Error & Beta & t & Sig. \\
\hline \multirow{2}{*}{$\begin{array}{c}\text { 1 Constant) } \\
\text { NewPU }\end{array}$} & 1.528 & .313 & & 4.882 & .000 \\
& .273 & .117 & .182 & 2.330 & .021 \\
\hline \multicolumn{5}{c}{ a. Dependent Variable: NewBI } \\
\hline
\end{tabular}

The Coefficients table (Table 4.26) provides information to explains BI in term of PU. The $\beta$ value is 0.273 in Table 4.26, which shows a positive relationship between the PU and BI. Therefore, as PU increase, BI will increase.

H3: There is a significant and positive relationship between PEOU and BI on social commerce.

Table 11. Model Summary of PEOU

\begin{tabular}{ccccc}
\hline \multicolumn{5}{c}{ Model Summary } \\
\hline Model & R & R Square & Adjusted R Square & Std. Error of the Estimate \\
\hline 1 & $.455^{\text {a }}$ & .207 & .202 & .67038 \\
\hline a. Predictors: (Constant), NewPEOU & & \\
\hline
\end{tabular}

Table 4.27 shows the model summary of BI and the PEOU. In the column labelled R, the value is 0.455 indicated that there is a positive and low correlation between the $\mathrm{BI}$ (outcome) and PEOU (predictor) in the model. Besides, the $\mathrm{R}^{2}$ is 0.207 which means that PEOU accounts for $20.7 \%$ as a cause of BI.

Table 12. ANOVA of PEOU

\begin{tabular}{|c|c|c|c|c|c|c|}
\hline \multicolumn{7}{|c|}{ ANOVA $^{\mathbf{a}}$} \\
\hline & Model & Sum of Squares & Df & Mean Square & $\mathbf{F}$ & Sig. \\
\hline \multirow{3}{*}{1} & Regression & 18.487 & 1 & 18.487 & 41.136 & $.000^{\mathrm{b}}$ \\
\hline & Residual & 71.007 & 158 & 449 & & \\
\hline & Total & 89.494 & 159 & & & \\
\hline $\begin{array}{l}\text { a. } \\
\text { b. }\end{array}$ & $\begin{array}{l}\text { pendent } \mathrm{Var} \\
\text { edictors: (Co }\end{array}$ & $\begin{array}{l}\text { ble: NewBI } \\
\text { tant), NewPEOU }\end{array}$ & & & & \\
\hline
\end{tabular}

Table 4.28 display that $F=41.136$ and the significant level is 0.05 in which the $p$-value of the finding is 0.000 , less than 0.05 . Thus, this model has explained a significant relationship between BI and PEOU.

Table 13. Coefficient of PEOU

\begin{tabular}{lllllll}
\hline \multirow{2}{*}{ Model } & \multicolumn{2}{c}{ Unstandardized Coefficients } & Standardized Coefficients & \multirow{2}{*}{ t } & \multirow{2}{*}{ Sig. } \\
\cline { 2 - 5 } & B & Std. Error & Beta & & \\
\hline \multirow{2}{*}{1} & (Constant) & .534 & .272 & & 1.964 & .051 \\
& NewPEOU & .645 & .101 & .455 & 6.414 & .000 \\
\hline \multicolumn{2}{l}{ a. Dependent Variable: NewBI } & & & & \\
\hline
\end{tabular}


The Coefficients table (Table 4.29) provides information to explain BI in term of PEOU. The $\beta$ value is 0.645 in Table 4.29 , which shows a positive relationship between the BI and PEOU. Therefore, as PEOU increase, BI will increase.

H4: There is a significant and positive relationship between PEOU and PU on social commerce.

Table 14. Model Summary of PEOU and PU

\begin{tabular}{lcccc}
\hline \multicolumn{5}{c}{ Model Summary } \\
\hline Model & $\mathbf{R}$ & R Square & Adjusted R Square & Std. Error of the Estimate \\
\hline 1 & $.611^{\mathrm{a}}$ & .373 & .369 & .39719 \\
\hline a. Predictors: (Constant), NewPEOU & & \\
\hline
\end{tabular}

Table 4.30 shows the model summary of PU and the PEOU. In the column labelled R, the value is 0.611 indicated that there is a positive and moderate correlation between the PU (outcome) and PEOU (predictor) in the model. Besides, the $\mathrm{R}^{2}$ is 0.373 which means that PEOU accounts for $37.3 \%$ as a cause of PU.

Table 15. ANOVA of PEOU and PU

\begin{tabular}{|c|c|c|c|c|c|c|}
\hline \multicolumn{7}{|c|}{ ANOVA $^{a}$} \\
\hline & & Sum of Squares & Df & Mean Square & $\mathbf{F}$ & Sig. \\
\hline \multirow{3}{*}{1} & Regression & 14.818 & 1 & 14.818 & 93.929 & $.000^{\mathrm{b}}$ \\
\hline & Residual & 24.926 & 158 & .158 & & \\
\hline & Total & 39.744 & 159 & & & \\
\hline & $\begin{array}{l}\text { ependent } \mathrm{Va} \\
\text { edictors: }(\mathrm{C}\end{array}$ & $\begin{array}{l}\text { able: NewPU } \\
\text { istant), NewPEOU }\end{array}$ & & & & \\
\hline
\end{tabular}

Table 4.31 display that $F=93.929$ and the significant level is 0.05 in which the $p$-value of the finding is 0.000 , less than 0.05 . Thus, this model has explained a significant relationship between PEOU and PU.

Table 16. Coefficients of PEOU and PU

\begin{tabular}{|c|c|c|c|c|c|}
\hline \multirow{2}{*}{ Model } & \multicolumn{2}{|c|}{ Unstandardized Coefficients } & \multirow{2}{*}{$\begin{array}{c}\text { Standardized Coefficients } \\
\text { Beta }\end{array}$} & \multirow{2}{*}{ t } & \multirow{2}{*}{ Sig. } \\
\hline & $\mathbf{B}$ & Std. Error & & & \\
\hline (Constant) & 1.088 & .161 & & 6.755 & .000 \\
\hline 1 NewPEOU & .578 & .060 & .611 & 9.692 & .000 \\
\hline
\end{tabular}

The Coefficients table (Table 4.32) provides information to explain PU in term of PEOU. The $\beta$ value is 0.5783 in Table 4.32 , which shows a positive relationship between the PEOU and perceived. Therefore, as PEOU increase, PU will increase.

H5: There is a significant and positive relationship between EWOM and BI on social commerce.

Table 17. Model Summary of EWOM

\begin{tabular}{ccccc}
\hline \multicolumn{4}{c}{ Model Summary } \\
\hline Model & $\mathbf{R}$ & R Square & Adjusted R Square & Std. Error of the Estimate \\
\hline 1 & $.354^{\mathrm{a}}$ & .125 & .120 & .70393 \\
\hline a. Predictors: (Constant), NewEWOM \\
\hline
\end{tabular}


Table 4.33 shows the model summary of BI and the EWOM. In the column labelled R, the value is 0.354 indicated that there is a positive and low correlation between the BI (outcome) and EWOM (predictor) in the model. Besides, the $\mathrm{R}^{2}$ is 0.125 which means that EWOM accounts for $12.5 \%$ as a cause of BI.

Table 18. ANOVA of EWOM

\begin{tabular}{lcccccc}
\hline \multicolumn{7}{c}{ ANOVA $^{\text {a }}$} \\
\hline & Model & Sum of Squares & df & Mean Square & F & Sig. \\
\hline & Regression & 11.203 & 1 & 11.203 & 22.609 & $.000^{\mathrm{b}}$ \\
1 & Residual & 78.291 & 158 & .496 & & \\
\multicolumn{2}{l}{ Total } & 89.494 & 159 & & & \\
\hline
\end{tabular}

Table 4.34 display that $\mathrm{F}=22.609$ and the significant level is 0.05 in which the $\mathrm{p}$-value of the finding is 0.000 , less than 0.05 . Thus, this model has explained a significant relationship between BI and EWOM.

Table 19. Coefficients of EWOM

\begin{tabular}{|c|c|c|c|c|c|}
\hline \multicolumn{6}{|c|}{ Coefficients $^{a}$} \\
\hline \multirow{2}{*}{ Model } & \multicolumn{2}{|c|}{ Unstandardized Coefficients } & \multirow{2}{*}{$\frac{\text { Standardized Coefficients }}{\text { Beta }}$} & \multirow{2}{*}{$\mathbf{t}$} & \multirow{2}{*}{ Sig. } \\
\hline & B & Std. Error & & & \\
\hline (Constant) & .750 & .319 & & 2.350 & .020 \\
\hline NewEWOM & .547 & .115 & .354 & 4.755 & .000 \\
\hline
\end{tabular}

The Coefficients table (Table 4.35) provides information to explain BI in term of EWOM. The $\beta$ value is 0.547 in Table 4.35 , which shows a positive relationship between the BI and EWOM. Therefore, as EWOM increase, BI will increase.

H6: There is a significant and positive relationship between SN and BI on social commerce.

Table 20. Model Summary of SN

\begin{tabular}{lcccc}
\hline \multicolumn{4}{c}{ Model Summary } \\
\hline Model & \multirow{2}{*}{ R } & R Square & Adjusted R Square Std. Error of the Estimate \\
\hline 1 & $.368^{\mathrm{a}}$ & .135 & .130 & .69989 \\
\hline a. Predictors: (Constant), NewSN & & \\
\hline
\end{tabular}

Table 4.36 shows the model summary of BI and the SN. In the column labelled R, the value is 0.368 indicated that there is a positive and low correlation between the BI (outcome) and $\mathrm{SN}$ (predictor) in the model. Besides, the $\mathrm{R}^{2}$ is 0.135 which means that $\mathrm{SN}$ accounts for $13.5 \%$ as a cause of BI.

Table 21. ANOVA of SN

\begin{tabular}{ccccccc}
\hline \multicolumn{7}{c}{ ANOVA $^{\mathbf{a}}$} \\
\hline & Model & Sum of Squares & df & Mean Square & F & Sig. \\
\hline \multirow{2}{*}{1} & Regression & 12.099 & 1 & 12.099 & 24.700 & $.000^{\mathrm{b}}$ \\
& Residual & 77.395 & 158 & .490 & &
\end{tabular}




\begin{tabular}{cccccc}
\hline \multicolumn{5}{c}{ ANOVA $^{\mathbf{a}}$} \\
\hline Model & Sum of Squares & df & Mean Square & F & Sig. \\
\hline Total & 89.494 & 159 & & & \\
\hline a. Dependent Variable: NewBI & & & & \\
b. Predictors: (Constant), NewSN & & & \\
\hline
\end{tabular}

Table 4.37 display that $\mathrm{F}=24.700$ and the significant level is 0.05 in which the $\mathrm{p}$-value of the finding is 0.000 , less than 0.05 . Thus, this model has explained a significant relationship between trust and BI.

Table 22. Coefficients of SN

\begin{tabular}{|c|c|c|c|c|c|}
\hline \multirow{3}{*}{ Model } & \multicolumn{5}{|c|}{ Coefficients $^{\mathrm{a}}$} \\
\hline & \multicolumn{2}{|c|}{$\begin{array}{l}\text { Unstandardized } \\
\text { Coefficients }\end{array}$} & \multirow{2}{*}{$\begin{array}{c}\begin{array}{c}\text { Standardized } \\
\text { Coefficients }\end{array} \\
\text { Beta }\end{array}$} & \multirow[t]{2}{*}{$\mathbf{t}$} & \multirow[t]{2}{*}{ Sig. } \\
\hline & B & Std. Error & & & \\
\hline \multirow{3}{*}{$\begin{array}{c}\text { (Constant) } \\
\text { NewSN }\end{array}$} & 1.224 & .212 & & 5.764 & .000 \\
\hline & .443 & .089 & .368 & 4.970 & .000 \\
\hline & ble: $\mathrm{N}$ & & & & \\
\hline
\end{tabular}

The Coefficients table (Table 4.38) provides information to explains BI in term of SN. The $\beta$ value is 0.443 in Table 4.38, which shows a positive relationship between the SN and BI. Therefore, as SN increase, BI will increase.

Table 23. Hypothesis Summary

\begin{tabular}{lcccc}
\hline No. & Hypothesis & $\begin{array}{c}\text { Significant } \\
\text { Value }\end{array}$ & $\begin{array}{c}\text { R } \\
\text { Squared }\end{array}$ & Status \\
\hline H1 & Trust - Behavioural Intention & $\mathrm{P}=0.00$ & 0.200 & Accepted \\
H2 & Perceived Usefulness - Behavioural Intention & $\mathrm{P}=0.00$ & 0.033 & $\begin{array}{c}\text { Accepted } \\
\text { H3 }\end{array}$ \\
H4 & PEOU - Behavioural Intention & $\mathrm{P}=0.00$ & 0.207 & Accepted \\
H5 & Electronic Word of Mouth - Behavioural Intention & $\mathrm{P}=0.00$ & 0.373 & Accepted \\
H6 & Subjective Norm - Behavioural Intention & $\mathrm{P}=0.00$ & 0.125 & Accepted \\
\hline
\end{tabular}

\section{Discussion and Conclusion}

\subsection{Finding of Results}

H1: There is a significant and positive relationship between Trust and BI on social commerce.

From the result, with $\beta=0.669$, the significance level is lower than $0.05(p=0.000)$, trust is making a significant contribution in determining BI in social commerce. Therefore, Hypothesis 1 is accepted. Trust had a significant positive regression weight $(\mathrm{p}=0.00, \mathrm{R}=$ 0.447 ) and it has the second highest value of prediction which is $20 \%$ among the other factors. Hence, trust is one of the considerations when the consumers shop online through the SMP especially the adolescent. The result of this research is consistent with (M. Krishna, et al., 2014), (Masoodul, Zeeshan, \& Bakhtawar, 2018) and (See, Khalil, \& Ameen, 2019). 


\section{H2: There is a significant and positive relationship between PU and BI on social commerce.}

According to the results of Table 5.1, it state that $\mathrm{H} 2$ with $\beta=0.273, \mathrm{R}=0.182$, $\mathrm{p}$-value $=$ $0.021>0.05$ denotes $\mathrm{PU}$ is a significant factor in determining $\mathrm{BI}$ of social commerce. Thus, $\mathrm{H} 2$ was supported at $95 \%$ confidence interval. Besides, PU is just 3.3\% can predict compare with other factors. Therefore, the hypothesis is affirm that the similar results obtained by the literature done by (Tan et al., 2017), (See, Khalil, \& Ameen, 2019) and (Seyedeh, Roliana, \& Aryati, 2014) which shown that PU is positively and significantly related to the BI among the young generation in social commerce. The higher the usefulness consumer received online; they are more likely to have intention to purchase online. In short, the easiness and functionality had successfully promoted the unique features of the Internet.

\section{H3: There is a significant and positive relationship between PEOU and BI on social commerce.}

Referring to the results of coefficient regression (Table 5.1), we can see that PEOU have significant effect on $\mathrm{BI}$, since the P-value $(\mathrm{p}=0.000)$ is greater than 0.05 . Hence, H3 was rejected at $95 \%$ confidence interval. Together, the $\beta$ of PEOU is 0.645 and R equal to 0.455 . Besides, it has the high value of prediction which is $20.7 \%$ among the other factors. As a result, PEOU is one of the considerations when the consumers shop online through the SMP especially the adolescent. The result of this research is consistent with (M. Krishna, et al., 2014), (Tan, Goh, Stany, \& Yeow, 2017) and (Francisco, Angel F., \& Manuel J, 2014).

H4: There is a significant and positive relationship between PEOU and PU on social commerce.

Referring to the results of coefficient regression from Table 5.1 state that $\mathrm{H} 4$ with $\beta=$ $0.578, \mathrm{R}=0.611, \mathrm{p}$-value $=0.000>0.05$ denotes PEOU is a significant factor in determining PU of social commerce. Thus, $\mathrm{H} 4$ was supported at $95 \%$ confidence interval. Besides, PU is just $3.3 \%$ can predict compare with other factors. Therefore, the hypothesis is confirming that has the similar results acquired by the literature done by (M. Krishna, et al., 2014), (Tan, Goh, Stany, \& Yeow, 2017) and (Francisco, Angel F., \& Manuel J, 2014) which shown that PEOU is positively and significantly related to the PU in social commerce. The higher PEOU of social commerce; consumers will be more aware of the usefulness of social commerce.

H5: There is a significant and positive relationship between EWOM and BI on social commerce.

From the result, with $\beta=0.547$, the significance level is lower than $0.05(p=0.000)$, EWOM is making a significant contribution in determining BI in social commerce. Therefore, Hypothesis 5 is accepted. EWOM had a significant positive regression weight $(\mathrm{p}=0.00, \mathrm{R}=$ 0.354 ) and it has a value of $12.5 \%$ prediction among the other factors. Therefore, EWOM is one of the considerations when the consumers shop online through the SMP especially the adolescent. The result of this research is consistent with (Sambashiva \& Acharyulu, 2017) and (Ramona, Asmidar, \& Norshakirah, 2016). 


\section{H6: There is a significant and positive relationship between $\mathrm{SN}$ and BI on social commerce.}

Referring to the results of coefficient regression (Table 5.1), we can see that SN have significant effect on BI, since the P-value $(\mathrm{p}=0.000)$ is greater than 0.05 . Hence, H6 was rejected at $95 \%$ confidence interval. Together, the $\beta$ of $\mathrm{SN}$ is 0.443 and $\mathrm{R}$ equal to 0.368 . Besides, it has the value of $13.5 \%$ prediction among the other factors. As a result, SN is one of the considerations when the consumers shop online through the SMP especially the adolescent. The result of this research is consistent with (Seyedeh, Roliana, \& Aryati, 2014) and (See, Khalil, \& Ameen, 2019).

\subsection{Recommendation for Results}

Based on the result analysis, PEOU is one of the most vital factors affecting the purchase intention on social commerce towards young generation in Malaysia Therefore, the researcher suggests that companies should improve the functionality and effectiveness of SMP. High effectiveness of search engine in SMP will influence consumers intend to purchase in that platform, because of the flexibility and understandable when searching and shopping through the SMP. As the result, the higher PEOU, the higher PU. Thus, there has a positive relationship between PEOU and PU. When improve the technology of social commerce, will influence the opinion of consumers toward the usefulness of the social commerce. Besides, the high flexibility and maintenance of the platform also will make the consumers think that social commerce is usefulness, in order to push the sales performance of this industry. Therefore, online retailers should design their websites to simplify the ordering process and delivery process, and provide consumers with enough detailed information. Hence, the consumers can use the platform to be more comfortably and conveniently when online shopping, in tend to improve the PU. In short, researcher highly recommend that companies should focus on the development on this area.

Last but not least, trust is the important element in social commerce as the findings shown, so the online retailers should enhance trust among consumers on online environments. To improve the trust between youth consumers and online retailers, online retailers should follow the rules and regulations by government policy, use the more advance, safety and high-tech security tools on the website to provide the safe transaction environment for their consumers.

\section{Implications}

In order to improve the growth of social commerce in Malaysia, this research created a fundamental study to further explore the effect of trust, PU, PEOU, EWOM and SN on Malaysian youth consumers' purchase intention toward social commerce. The two parties, government and social commerce industry will get the implications form this research.

\subsection{Government}

For the government, this research will help them to analyse the current situation of social commerce, and become the auxiliary data for government to implement the policy in order to develop this social commerce sector. When government vigorously promote and develop the social commerce in Malaysia, the purchase intention towards social commerce will increase, 
which also will be driving the Malaysian economy. Not only that, social commerce is the combination of internet technology and commercial, in response to the development of social commerce, government should pay attention to the development of internet networking and SMP technology. If not, this issue will become serious in the development on social commerce in Malaysia.

\subsection{Social Commerce Industry}

For social commerce industry, marketers can predict the BI of consumers and analyse the current performance of social commerce in Malaysia, in order to improve the marketing strategy and performance in future and find the potential business opportunity in social commerce industry. However, if the healthcare industry does not consider these factors when developing marketing strategy, they cannot understand the young generation purchase intention toward social commerce and may implement the unsuitable marketing plan, it will weaken the sustainability of the business in this sector. Therefore, social commerce industry can implement the most suitable and perfect marketing plan by using this research as the fundamental resources.

\subsection{Conclusion}

In conclusion, the main purpose of this research is to analyse the factors that will affect purchase intention toward social commerce by young generations in Malaysia and to investigate do the variables have significant and positive relationship towards social commerce in Malaysia. Followed the theoretical fundamentals from previous literatures, a conceptual model provided by this research which was proposed by integrating trust, PU, PEOU, EWOM and SN with youth consumers' online purchase intention. The results of this research revealed that all the independent variables have direct positive and significant effect on young generations online purchase intention toward social commerce in Malaysia. Hence, the online retailers and marketers should emphasis and be more focus on these area in order to increase their competitiveness, especially the Trust, PU and PEOU.

\section{References}

[1] Abdullah, S., Ahasanul, H., \& Farzana, Y. (2013). The Usage of Social Network as a Marketing Tool:. International Journal of Academic Research in Economics and Management Sciences.

[2] Ajzen, I. (1985). From Intentions to Actions: A Theory of Planned Behavior. Action Control. Action Control, 11-39. doi:10.1007/978-3-642-69746-3 2

[3] Akanbi, O. A., Amiri, I. S., \& Fazeldehkordi, E. (2015). A Machine-Learning Approach to Phishing Detetion and Defense .

[4] Ali, Z., \& Bhaskar, S. B. (2016). Basic statistical tools in research and data analysis. Indian Journal of Anaesthesia, 60(9), 662-669.

[5] Borgatti, S., \& Cross, R. (2003). A Relational View of Information Seeking and Learning in Social Networks. Management Science, 432-445.

[6] Burney, S., \& Saleem, H. (2008). Inductive and Deductive Research Approach. Faculty of Arts and Science. doi:10.13140/RG.2.2.31603.58406 
[7] Catherine, D., Starr, R. H., \& Katia, P. (2007). Trust and Privacy Concern Within Social Networking Sites: A Comparison of Facebook and MySpace. Americas Conference on Information Systems.

[8] Cheung, M. Y., Luo, C., Sia, C. L., \& Chen, H. (2009). Credibility of Electronic Wordof-Mouth: Informational and Normative Determinants of On-line. International Journal of Electronic Commerce, 13(4), 9-38. doi:10.2753/JEC1086-4415130402

[9] CRONBACH, L. J. (1951). COEFFICIENT ALPHA AND THE INTERNAL STRUCTURE OF TESTS. PSYCHOMETRIK, 16(3), 297-334.

[10] Cronbach, L. J. (1951). Coefficient alpha and the internal structure of tests. Psychomet rika, 16(8), 297-334.

[11] Curty, Renata, \& Zhang, P. (2011). Social Commerce: Looking Back and Forward. Proceedings of the American Society for Information Science and Technology (ASIST) Annual Conference.

[12] Das, K. R., \& Imon, A. H. (2016, January). A Brief Review of Tests for Normality. American Journal of Theoretical and Applied Statistics, 5(1), 5-12. doi:10.11648/j.ajtas.20160501.12

[13] Data Reportal. (2020). Retrieved from Global Digital Report 2020: https://datareportal.com/reports/digital-2020-global-digital-overview

[14] Davis, F. (1989). Perceived Usefulness, Perceived Ease of Use, and User Acceptance of Information Technology. MIS Quarterly, 13(3), 319-340. doi:10.2307/249008

[15] Davis, F. D. (1989). Perceived Usefulness, Perceived Ease of Use, and User Acceptance of Information Technology. Management Information Systems Research Center, University of Minnesota, 22.

[16] Davis, F. D. (1989, September). Perceived Usefulness, Perceived Ease of Use, and User Acceptance of Information Technology. MIS Quarterly, 13(3), 319-340.

[17] Davis, F. D. (1991). User Acceptance of Information Technology: System Characteristics, User Perceptions and Behavioral Impacts. International journal of man-machine studies, 475-487.

[18] Dimagi. (2020). Data Collection: How to Get Started. Retrieved from Dimagi: https://www.dimagi.com/data-collection/

[19] Doane, D. P., \& Seward, L. E. (2011). Measuring Skewness: A Forgotten Statistic? Journal of Statistics Education, 19(2), 18. Retrieved from http://www.amstat.org/publications/jse/v19n2/doane.pdf

[20] Dodds, W., Monroe, K., \& Grewal, D. (1991). Effects of Price, Brand and Store Information on Buyers' Product Evaluations . Journal of Marketing Research.

[21] E Marketer. (2019, August 22). Retrieved from Social Commerce Leads Consumer Adoption of New Retail Technology: https://www.emarketer.com/content/socialcommerce-leads-consumer-adoption-of-new-retail-technology

[22] Econsultancy. (2019). Retrieved from The State of Social Commerce in Southeast Asia: https://econsultancy.com/is-social-commerce-finally-taking-off-in-southeast-asia/

[23] Fishbein, M., \& Ajzen, I. (1975). Belief, Attitude, Intention and Behaviour: An Introduction to Theory and Research.

[24] Flanagin, A. J., \& Metzger, M. J. (2007). The role of site features, user attributes, and information verification behaviors on the perceived credibility of web-based information. New Media \&Society, 319-342.

[25] Foucault, B. E., \& Scheufele, L. (2008). Internet versus bricks and mortar retailers: an investigation into intangibility and its consequences. Journal of Retailing, 251-267. 
[26] Francisco, L.-C., Angel F., V.-R., \& Manuel J, S.-F. (2014). MOBILE SOCIAL COMMERCE ACCEPTANCE MODEL: FACTORS AND INFLUENCES ON INTENTION TO USE S-COMMERCE.

[27] Fricker, R. D., \& Schonlau, M. (2002). Advantages and Disadvantages of Internet Research Surveys: Evidence from the Literature. Field Methods, 14(4), 347-367.

[28] Gefen, D., Karahanna, E., \& Straub, D. W. (2003, March). Trust and TAM in online shopping: An integrated model. MIS Quarterly, 27(1), 51.

[29] Ghasemi, A., \& Zahediasl, S. (2012). Normality Tests for Statistical Analysis: A Guide for Non-Statisticians. International Journal of Endocrinol Metabolism, 10(2), 486-489. doi:10.5812/ijem.3505

[30] Grant, C., \& Osanloo, A. (2014). Understanding, Selecting, and Intergrating a Theoretical Framework in Dissertation Research: Creating The Blueprint for Your "House". Administrative Issues Journal: Connecting Education, Pratice, and Research, 4(2), 12-26.

[31] Heale, R., \& Alison, T. (2015). Validity and reliability in quantitative studies. Evid Based Nurs, 18(3), 66-67. doi:10.1136/eb-2015-102129

[32] Hinkle, D., Wiersma, W., \& Jurs, S. (2003). Applied Statistics for the Behavioral Sciences. Boston: Houghton Mifflin.

[33] IBM®. (2020). KMO and Bartlett's Test. Retrieved from IBM Knowledge Center: https://www.ibm.com/support/knowledgecenter/SSLVMB_23.0.0/spss/tutorials/fac_tel co_kmo_01.html

[34] John, D. (2018, January). Data Collection Methods. Retrieved from Research Methodology: https://research-methodology.net/research-methods/data-collection/

[35] Kabir, S. M. (2016, July). METHODS OF DATA COLLECTION. Basic Guidelines for Research, 201-275.

[36] Khalil, M. N., \& Michael, P. (2008). An Exploratory Study Into the Adoption of Internet Banking in a Developing Country: Malaysia. Journal of Internet Commerce, 29-73.

[37] Kim, H.-Y. (2013). Statistical notes for clinical researchers: assessing normal distribution (2) using skewness and kurtosis. Restorative Dentistry \& Endodontics, $38(1), 52-54$.

[38] Krejcie, R. V., \& Morgan, D. W. (1970). Determining Sample Size for Research Activities. Educational and Psychological Measurement, 30, 607-610.

[39] Leon, A. C., Davis, L. L., \& Kraemer, H. C. (2011). The role and interpretation of pilot studies in clinical research. Journal of Psychiatric Research, 45(5), 626-629. doi:10.1016/j.jpsychires.2010.10.008

[40] Leong, L.-Y., Noor, I. J., \& Sulaiman, A. (2018). UNDERSTANDING FACEBOOK COMMERCE (F-COMMERCE) ACTUAL PURCHASE FROM AN ARTIFICIAL NEURAL NETWORK PERSPECTIVE. Journal of Electronic Commerce Research, 75-103.

[41] Li, H., \& Reima, S. (2009). A Proposed Scale for Measuring E-service Quality. International Journal of $u$ - and e-Service.

[42] M. Krishna, M., Chan, W. S., Chan, Y. L., Tee, P. Y., Wan, K. Y., \& Yip, Y. E. (2014). Adoption of Mobile Commerce in Malaysia: A Generation Y Perception. International Journal of Research, 825-845.

[43] Market Business News. (2020). Retrieved from What is social commerce? Definition and meaning: https://marketbusinessnews.com/financial-glossary/social-commercedefinition-meaning/ 
[44] Mary, G., Graham, J. L., Mary, C., \& Yale, L. J. (1998). A Dyadic Study of InterpersonalInformation Search. Journal of the Academy of Marketing Science, 83100.

[45] Mashau, T. S., \& Mutshaeni, H. N. (2013). Implementation of Legislations and Policies: Case Study of Vhembe and Mopani Districts' School Principals in Limpopo Province. Journal of Education and Human Development, 30-41.

[46] Masoodul, H., Zeeshan, I., \& Bakhtawar, K. (2018). The Role of Trust and Social Presence in Social Commerce Purchase Intention. Pakistan Journal of Commerce and Social Sciences, 111-135.

[47] Mayer, R. C., Davis, J. H., \& Schoorman, F. D. (1995). AN INTEGRATIVE MODEL OF ORGANIZATIONAL TRUST. The Academy of Management Review, 709-734.

[48] Morris, A. S. (2001). Measurement and instrumentation principles. Butterworth Heinemann.

[49] Odom, L. R., \& Morrow, J. J. (2006). What's this r? A Correlational Approach to Explaining Validity, Reliability and Objectivity Coefficients. Measurement in Physical Education and Exercise Science, 10(2), 137-145. doi:10.1207/s15327841mpee1002_5

[50] Othman, A., \& Ibrahim, A. (2013). Towards lean construction: using quality management as a tool to minimise waste in the Egyptian construction industry. South African Council for the Quantity Surveying Profession.

[51] Park, J. H. (2002). THE EFFECT OF PRODUCT PRESENTATION ON MOOD, PERCEIVED RISK,. ProQuest Information and Learning Company .

[52] Ramona, R., Asmidar, A. B., \& Norshakirah, A. (2016). Review of Literature on Trust Factors Affecting Customer's Purchase Intention on SOHO seller: S- Commerce Context. International Information Institute, 2791-2796.

[53] Reja, U., Manfreda, K. L., Hlebec, V., \& Vehovar, V. (2003). Open-ended vs. Closeended Questions in Web Questionnaires. (A. Ferligoj, \& A. Mrvar, Eds.) Developments in Applied Statistics, 159-177.

[54] Rogers, E. M. (1983). DIFFUSION OF INNOVATIONS. New York: A Division of Macmillan Publishing Co., Inc.

[55] Saeideh, S. f., Ezhar, T., M. S., Moniza, W., \& Zeinab, Z. (2016). Factors affecting Malaysian university students' purchase intention in social networking sites. Cogent Business Management, 12.

[56] Sambashiva, R. K., \& Acharyulu, G. (2017). Examining the effect of eWOM on the customer purchase intention through value co-creation (VCC) in social networking sites (SNSs). Management Research Review, 245-269.

[57] Saunders, M., Lewis, P., \& Thornhill, A. (2009). Research Methods for Business Students (5th ed.). England: Pearson.

[58] Saunders, M., Lewis, P., \& Thornhill, A. (2012). Research methods for business. United Kingdom: England: Pearson Education Limited.

[59] Saunders, M., Lewis, P., \& Thornhill, A. (2012). Research Methods for Business Students (6th ed.). Pearson Education Limited.

[60] Schlegel, D. (2015). In Cost-of-Capital in Managerial Finance. Springer International Publishing, 97-106.

[61] See, S. S., Khalil, M. N., \& Ameen, M. A.-A. (2019). FACTORS INFLUENCING CONSUMERS' ONLINE PURCHASE INTENTION IN SOCIAL COMMERCE AMONG MILLENNIALS IN MALAYSIA. Qualitative and Quantitative Research Review, 171-194. 
[62] Seyedeh, M. M., Roliana, I., \& Aryati, B. (2014). Understanding factors on the customer intention behavior through Facebook commerce: a conceptual model. International Symposium on Technology Management and Emerging Technologies, 107-112.

[63] Smith, C. (2015, October 23). Facebook is leading the way in social commerce. Retrieved from Business Insider: https://www.businessinsider.com/social-commerce2015-report-2015-7?IR=T

[64] Statista. (2019). Retrieved from Social Commerce: https://www.statista.com/topics/1280/social-commerce/

[62] Stevens, S. S. (1946, June 7). On the Theory of Scales of Measurement. Science, 677680.

[63] Sylvie, A., Don, F., \& LeBrasseur, R. (November 4, 2008). Network communities: strategies for digital collaboration. In S. Albert, D. Flournoy, \& R. LeBrasseur. Information Science Reference; 1 edition.

[64] Taherdoost, H. (2016). Validity and Reliability of the Research Instrument; How to Test the Validation of a Questionnaire/ Survey in a Research. International Journal of Academic Research in Management, 5(3), 28-36.

[65] Tan, P. K., Goh, H. B., Stany, W. L., \& Yeow, J. A. (2017). FACTORS THAT INFLUENCE THE CONSUMER PURCHASE INTENTION IN SOCIAL MEDIA WEBSITES. 3rd International Conference on Advanced Research in Business and Social Sciences, 214-221.

[66] Taylor, S., \& Todd, P. A. (1995, June). Understanding Information Technology Usage: A Test of Competing Models. Information Systems Research, 6(2), 144-176.

[67] Today, S. C. (2011, January 23). Social Commerce Definition. Retrieved from Social Commerce Today: https://socialcommercetoday.com/social-commerce-definitionword-cloud-definitive-definition-list/

[68] Trybocka, A. (2019, December 18). Cresco Data. Retrieved from The Rise of Social Commerce in Southeast Asia and Emerging Trends: https://crescodata.com/the-rise-ofsocial-commerce-in-southeast-asia-and-emerging-trends/

[69] Turban, E., King, D., Lee, J., Liang, T.-P., \& Turban, D. (2015). Electronic Commerce: A Managerial and Social Networks Perspective. Springer Texts in Businedd and Economic.

[70] V'elez, J. I., \& Morales, J. C. (2015). A modified Q-Q plot for large sample sizes. Comunicaciones en Estad'istica, 8(2), 163-172.

[71] Venkatesh, V., \& Davis, F. D. (2000). A Theoretical Extension of the Technology Acceptance Model: Four Longitudinal Field Studies. Management Science, 186-204.

[72] Zailinawati, A. H., Schattner, P., \& Mazza, D. (2006). Doing a pilot study: Why is it essential? Malaysian Family Physician, 1(2\&3), 70-73.

[73] Zikmund, W. G. (2003). Business Research Methods (7th ed.). Thomson Southwestern.

[74] Zikmund, W. G., Babin, B. J., Carr, J. C., \& Griffin, M. (2009). Business Research Methods (8th ed.). USA, Ohio: South-Western Cengage Learning.

[75] Zohrabi, M. (2013). Mixed Method Research: Instruments, Validity, Reliability and Reporting Findings. Theory and Practice in Language Studies, 3(2), 254-262. doi:10.4304/tpls.3.2.254-262 